\title{
The Tension between Due Process of Law and Counter-Terrorist Measures During the Initial Stages of Criminal Procedure
}

\author{
LIMOR EZIONI*
}

\section{Introduction}

This article reviews how the Israeli criminal system uses secret evidence ${ }^{1}$ during the initial stages of criminal procedure, and questions whether it should allow the use of such evidence. More specifically, should terror suspects be afforded the same criminal procedure as regular criminal suspects, or should the procedure differ when it comes to secret evidence? Identifying which underlying theory guides a country's criminal system is necessary to understand what the goals of that system are. Thus the answer to this question may be found in the dichotomous models of criminal process.

The tensions that always existed between the two traditional models of criminal procedure - due process and crime control - are today sharper than ever. While criminal procedure in many legal systems traditionally leans toward due process values, the terrorist threat requires an efficient crime control model in order to protect national security interests. In the Israeli context it is especially challenging to determine which model and values should be preferred, given Israel's fragile security situation on the one hand, and its commitment to human rights on the other. This tension is especially poignant when it

LL.D, vice dean of Shaarei Mishpat Academic Centre, Israel; Impressions of the conference on secret evidence, counter-terrorism and criminal procedure, Israel 2013.

1 Secret evidence is defined as evidence, classified or unclassified, that is not disclosed to the accused themself, see on this definition:. Note, Secret Evidence in the War on Terror, 118 Harv. L. Rev. 1962, n. 7 (2005), as cited in Moranchek, Protecting National Security Evidence While Prosecuting War Crimes: Problems and Lessons for International Justice from the ICTY, 31 Yale J. Int'l L (2006), p. 477ff., at 489, footnote 58; Yaroshefsky, Secret Evidence Is Slowly Eroding the Adversary System: CIPA and FISA in the Courts, 34 Hofstra L. Rev. (2005-2006), p.1063ff., at 1064 , footnote 3 .

This is an Open-access article distributed under the terms of the Creative Commons Attribution 3.0 Unported License (http://creativecommons.org/licenses/ by/3.0/), permitting all use, distribution, and reproduction in any medium, provided the original work is properly cited. 
comes to the use of secret evidence during the initial stages of criminal procedure against suspected terrorists. Comparative literature published in both international and domestic fora may help shed some light on how best to balance the use of secret evidence with civil liberties. New Israeli legislation can also indicate the direction criminal procedure will be taking in the future. All of these topics will be addressed below.

\section{Due Process vs. Crime Control: The traditional tension and its application to the use of secret evidence}

\subsection{Crime Control}

The procedural norms of a criminal system depend on its predisposition to employ either the model of crime control or of due process, as originally introduced by Herbert Packer. ${ }^{2}$ The basis of the crime control model is the repression of criminal conduct, and efficiency is accentuated. The apprehension and conviction of criminals without delay due to procedure will determine whether system is successful. The crime control model assumes that the system enforces the law by convicting guilty suspects, and does away with superfluous procedures by expediting their detention. ${ }^{3}$ There is little or no focus on how to assist a suspect or defendant in mounting their defence, and an assumption that this will lead to a better, more law-abiding society. There is no question of purposely arresting or convicting innocent parties - this is strictly off limits - but there is an encouragement to minimise procedural bureaucracy. Under this system the use of secret evidence would be deemed to lend efficiency to the system.

Therefore, evidential screening processes that lead to an early determination of guilt or innocence are necessary, making the early stages of the criminal process the important ones, and doing away with procedural hurdles to bring about a quick end to the case. In this way, those responsible for the early stages of an investigation, like the security agency employee collecting evidence or a prosecutor who decides whether or not to pursue a case, almost become judges themselves. They must determine whether or not the suspect is guilty. As long as the administrative fact-finding activities are reliable, this "presumption of guilt" encourages efficiency in the system by allowing it to deal quickly with a large number of cases. ${ }^{4}$ The less restrictions there are, the more efficient the system will be.

2 Packer, The Limits of the Criminal Sanction (Stanford University Press 1968), pp. 149-173.

$3 \quad$ Ibid., pp. 4-6.

$4 \quad$ Ibid., p. 5. 


\subsection{Due Process}

The idea behind the due process model rests on the absolute importance of the formal structure of the law. This means that while the crime control model bestows faith on the reliability of the investigative and prosecutorial offices, the due process model assumes a possibility of error, and insists on formal legal processes under which the accused has every opportunity to disprove the evidence built against them. In due process, reliability stems from the full adjudicative process playing itself out, and not from those who gather evidence at the early stages. The best way of repressing crime under the due process model is to heed legal guilt, or whether a suspect can be convicted in court, even if this means ignoring factual guilt. ${ }^{5}$ The final component of the due process model is the principle of equality of arms. ${ }^{6}$ Whether the use of secret evidence is supported or opposed by this understanding of equality may depend on when evidence is introduced into the system.

\subsection{The Two Models and the Use of Secret Evidence}

Defendants sometimes assume that full access to the evidence in their case is like a black box - if they have the key, they can prove their innocence immediately. Even if the evidence is incriminating, the suspect may be able to pose legal arguments that sufficiently challenge the case. In cases where the system is trying to protect society from acts of terrorism, the crime control model would not consider this efficient by any means. ${ }^{7}$ Now consider the opposite example - an innocent suspect is mistakenly convicted or detained, their right to freedom of movement severely restrained, and they are restricted from adequately defending their case. This would be a travesty under the due process model. ${ }^{8}$

It may be argued that the crime control model weakens the rights of the individual and the due process model weakens the rights of the community. ${ }^{9}$ Even if the matter is more complex, this simplification highlights who is typically considered to benefit from each model, which is especially relevant when it comes to terrorism. Theoretically, under the crime control model, sharing evidence with the defence will not change the presumption of guilt, but will only give the defendant the opportunity to challenge it via the judicial process. Efficiency is at its best when the decision of whether or not to prosecute a terror suspect is left to the prosecutors and judges. Furthermore, the balancing act that judges must perform between a suspect's rights and state security should achieve the

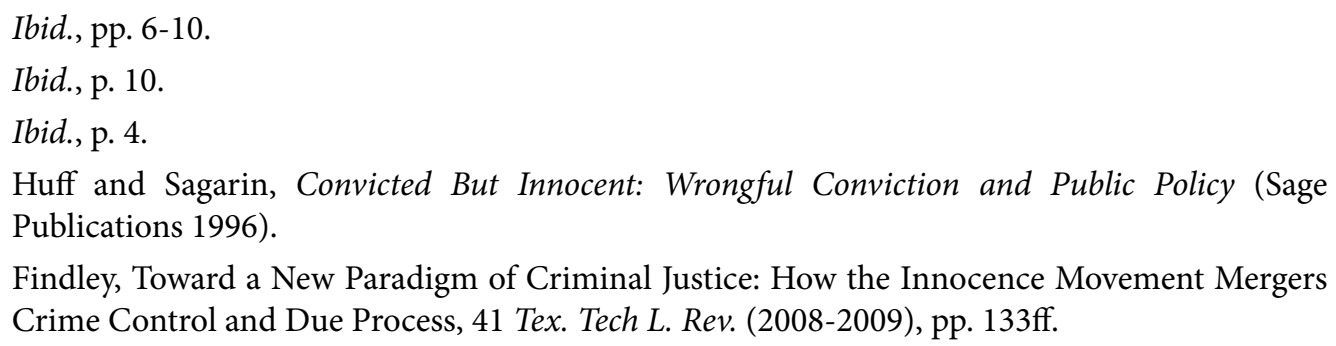


equality that the due process model pursues - by subjecting everyone to the same legal standards. The due process model supports the idea of "legal innocence" and rejects the crime control model's "presumption of guilt". Not only are the fact-finding capabilities of the police and the prosecution considered unreliable, they are also considered biased. Additionally, factual nuances that would help to prove the defendant's innocence may come to light only if the defence is allowed access to the secret evidence against them.

\section{Israeli Criminal Procedure}

\subsection{Terror Suspects vs. Regular Criminal Defendants}

An important starting point in considering what should define due process values for a terrorist suspect depends on whether the criteria that compose regular criminal due process remain the same when the defendant is a suspected terrorist. A high proof standard applies and suspects must be proven guilty beyond a reasonable doubt if the law decides to limit their freedom. This due process system prevents false positives by avoiding the conviction of innocents, but at the risk of allowing false negatives when it potentially lets the guilty go free. ${ }^{10}$ This also means that due process values such as liberty trump national security interests. However, both criminal law and international humanitarian law, two completely different paradigms, may apply to the cases of terror suspects. ${ }^{11}$ When it comes to regulating the use of secret evidence in arrest cases, each has very different criteria with regards to due process values.

Let us assume that the goal of criminal procedure is to prevent criminal activity, which endangers individuals in society. If the goals of criminal procedure reflect the same goals in relation to preventing terrorism, then terror suspects should be afforded the same rights as criminal defendants. However, a murderer who kills with intent cannot be directly compared to a terrorist that infiltrates national security and intentionally targets a crowded building, when this person is not at all deterred by criminal punishment. The goal of trying terror suspects has similar traits with trying criminal suspects but is not the same - it is an attempt to prevent terrorist acts that are intended to harm national security. The scale is largely different. ${ }^{12}$

Another difference between traditional criminal suspects and terror suspects is that in regular criminal trials a defendant is being investigated and tried for a crime he or she have already committed. A terrorist suspect, however, may be detained for an act that he or she has yet to commit, in an effort to protect potential victims. This is relevant in legal

\footnotetext{
10 Waxman, Detention as Targeting: Standards of Certainty and Detention of Suspected Terrorists 108 Colum. L. Rev. (2008), p. 1365ff., at 1372.

$11 \quad$ Ibid.

12 Posner, Not a Suicide Pact (OUP 2006) pp. 64-65.
} 
procedures such as preventive detention where members of a terrorist organisation may be held in order to thwart them from committing a crime. If this is the case, limiting a suspect's liberty based on secret evidence for an act that has not yet materialised becomes even more tenuous, as criminal procedure rests on the basis of punishing only the factually guilty, and not the potentially guilty. ${ }^{13}$

Israeli legislation as such, however, may indicate that a law of war paradigm is more relevant. Indeed, both the military order that governs the detentions of Palestinians from the West Bank and the law on the Incarceration of Unlawful Combatants indicate that this is so. The first is an outright military order, as per Israel's belligerent occupation of the West Bank. The second allows the detention of unlawful foreign combatants based on an international armed conflict between Israel and terrorist organisations that operate outside of it. ${ }^{14}$ Other countries, such as the US, have decided to apply the war paradigm in order to effectively combat terrorism. ${ }^{15}$ The theory, as it goes, is that it may be impossible to meet the criminal conviction standard when assessing membership in a terrorist organisation because of privileged evidence that is too dangerous to disclose. ${ }^{16}$

The difficulty is that neither criminal law nor the laws of war have proven to be effective deterrents against terrorists. Since the first is aimed at punishing prior acts, or more accurately deterring those acts with threat of punishment, it offers no solution for the case of the offender who has already served their sentence but who continues to pose a serious risk for people on the street. ${ }^{17}$ The second makes it difficult to establish who qualifies as a combatant under unconventional warfare, how long this warfare lasts, and does not adequately safeguard the civil liberties of those who are detained. ${ }^{18}$ The choice between the criminal paradigm or a warfare paradigm is therefore a deceptive choice. They might be used simultaneously, or to supplement one another.

By supplementing criminal law to allow it to deter future terrorist acts as well, it may be possible to hold true to its original purpose. ${ }^{19}$ This method is already used in other areas, such as preventive detention for the mentally ill, sexual offenders and mob activity. ${ }^{20}$ In the same vein, if a suspect poses imminent and serious danger to society they

13 Roach and Trotter, Miscarriages of Justice in the War Against Terrorism, 109 Penn. St. L. Rev. (2005), p. 967ff., at 968.

14 Krebs, Lifting the Veil of Secrecy: Judicial Review of Administrative Detentions in the Israeli Supreme Court, 45 Vand. J. Transnat'l L. (2012), p. 639ff, at 663.

15 Waxman 2008, p. 1374.

16 Guiora, Legislative and Policy Responses to Terrorism, A Global Perspective, 7 San Diego Int'l L.J. (2005), p. 125ff.

17 Martin, Preventive Detention - Restricting the Freedom to Harm, 8 JIJIS (2008), p. 166ff., at 170-171.

$18 \quad$ Ibid..

$19 \quad$ Note, Responding to Terrorism, op.cit., p. 1231.

$20 \quad$ Martin 2008, p. 176. 
should be prevented from destroying public safety. Incorporating due process values into a preventative method is possible. Setting a lower standard of proof may for example be supplemented by requiring a higher level of violence. ${ }^{21}$ A punitive sentence and a preventive one may then be considered to serve the same purpose of deterring criminal and terrorist acts. When examining the correct way of suppressing such acts, we must decide between a desire for straightforward efficiency as opposed to an emphasis on appropriate legal procedure. This leads us back again to our original models of criminal procedure. The use of secret evidence will then be tailored based on which model is to be preferred. Should secret evidence encourage efficiency, it might well be justified as an exceptional measure. Should it seriously impede due process, however, its use must be suppressed.

\subsection{Philosophical and Political Underpinnings of the Israeli Criminal Justice System}

As noted above, routine criminal trials have a view to incarcerate those who are guilty beyond a reasonable doubt, but terror suspects who endanger a large number of civilian lives may require a different kind of procedure - one that is more disposed to limit their liberty. ${ }^{22}$ Depending on which model a society adopts, its criminal procedure and the application of its directives will be greatly affected. The question of which model is preferable for a given society must be analysed on a case-by-case basis. The beliefs and philosophical underpinnings of each society's justice system play a central role in answering this question.

For example whether a judicial system has an inquisitorial or adversarial style may affect the choice of model. Inquisitorial traditions seek Truth (capital ' $T$ ') while adversarial systems search for truth. ${ }^{23}$ The former refers to an absolute Truth with the correct law being applied after an extensive search for a full factual account of the incidents in question, while the latter means that the system seeks a truth balanced with other values, such as individual rights. Thinkers such as Plato, Thomas Hobbes and Baruch Spinoza set forth the philosophy behind the inquisitorial tradition. This tradition entrusts the state with society's security, and the authorities are trusted to use whatever methods are necessary. The benefit to individuals can only be achieved if they subordinate themselves to the state's methods - and in this way the inquisitorial tradition seems to conform to the crime control model. ${ }^{24}$ Meanwhile, the adversarial process seems to reflect the due process model - the correct legal process must be followed and trumps the 'Truth' if evidence is obtained illegally or unjustly.

\footnotetext{
$21 \quad$ Martin 2008, p. 167.

22 Waxman 2008

23 King, Security, Scale Form, and Function: The Search for Truth and the Exclusion of Evidence in Adversarial and Inquisitorial Justice Systems, 12 Int'l Legal Persp. (2001-2002), p. 185ff.

$24 \quad$ Ibid., pp. 192-193.
} 
In addition to their philosophical background, certain countries seem to prefer one model over the other based on either liberal or conservative social values and on the country's political climate. Israel is unique in that it has a rather social-democratic-structured society and its population supports liberal values, but its security concerns determinedly outweigh other national factors, pulling it back towards a crime control model. When it comes to terrorism, which is the country's foremost security threat since its foundation in 1948, there is little room for flexibility in the criminal justice system and the prosecution of terrorists. Israel has always maintained due process values common to other democracies, which is reflected in its criminal procedure and active judiciary. ${ }^{25}$

Given these unique characteristics, it is unsurprising that Israel has struck a compromise between the two models of the criminal justice system with their opposing ideologies. The way in which these values have manifested into evidential procedure exemplifies this. When it comes to secret evidence in the Israeli system there is a two-part process. First, the police and prosecutor are able to use secret evidence when deciding whether or not to pursue a case. Once a party transitions from being a suspect to a defendant, a judge may see and hear secret evidence ex parte, to determine whether or not that evidence is essential to the defence's case, both when deciding administrative detention hearings and during the case itself. While the Israeli justice system is based on the adversarial tradition, inherited from its British predecessors, its judges are expected to take on a much more inquisitorial role in their active fact-gathering. ${ }^{26}$ However, this occurs without either the defendant or the defence lawyer ever having the opportunity to see the evidence themselves. Hence an interesting tension is struck between crime control and due process.

\subsection{Applying models}

\subsubsection{Privileged Evidence in the Initial Stages of Israeli Criminal Proceedings}

Herbert Packer's theoretical due process model must be translated into practical legal process. The concept of due process has generally been interpreted to mean the right of the accused to know what are the charges against them, as well as have access to the evidence supporting those allegations so that they may attempt to refute them. ${ }^{27}$ Even where the general rule of disclosure is limited with secret evidence for reasons such as nation-

25 Blum, Preventive Detention in the War on Terror: A Comparison of how the United States, Britain and Israel Detain and Incapacitate Terrorist Suspects, IV Homeland Security Affairs (2008), p. 3ff., at 13.

26 Barak-Erez and Waxman, Secret Evidence and the Due Process of Terrorist Detentions, 48 Colum. J. Transnat'l Law (2009), p. 3ff., at 40.

27 Van Harten, Charkaoui and Secret Evidence, 42 Sup. Ct. L. Rev. $2 d$ (2008), p. 251ff., at 252, as cited by Barak-Erez and Waxman 2009, p. 36. 
al security interests, the accused must nevertheless be made aware of the substance or thrust of the case against them. ${ }^{28}$ To which extent may disclosure be limited by national security interests in such cases? In the case of Israeli criminal procedure, this depends on the judge.

The process is as follows: in the initial phase, the police and security agencies collect material for an investigation and transfer it to the prosecution. Section 74 of the Israeli code of criminal procedure then requires that both the accused and their lawyer be able to inspect all investigation materials in the possession of the prosecutor. ${ }^{29}$ The only way this can be prevented is through the use of rules on "privileged evidence" or secret evidence, whereby a relevant minister signs a 'certificate of opinion' that such evidence is likely to impair state security, foreign relations, or an important public interest. ${ }^{30}$ The prosecution has an obligation to notify the defense if a certificate of privilege has been obtained, and to inform them of the thrust or essence of the privileged evidence. ${ }^{31}$ Privileged evidence is inadmissible at trial for both the prosecution and the defence.

Should the defence petition to have the evidence disclosed, ${ }^{32}$ the petition is heard in camera and ruled on by a judge of the Supreme Court. During this hearing, the judge may demand to see the evidence and ask questions of the prosecutor or a representative from the relevant ministry that signed the 'certificate of opinion'. A test must follow balancing the possible harm to the defendant against the possible harm to public interest, or in other words the value of a fair trial versus state security. The verdict Livny v. Israel narrowed the application of this test, and dictated that if the privileged evidence is essential to the defence, it must be disclosed no matter what public or security interests are at stake. ${ }^{33}$ The value of a fair trial, according to Justice Barak, was based on revealing all evidence to the suspect. If it is unclear whether or not the evidence is essential to the defence's case, the court must then revert back to weighing the importance of the evidence against security interests. ${ }^{34}$

There are thus three checks in Israeli criminal procedure when it comes to secret evidence. Firstly, the prosecutor must decide to activate the rules of privilege. Secondly, the minister signing the 'certificate of opinion' must be convinced that exposing the enclosed information would impair state security, foreign relations or the public interest.

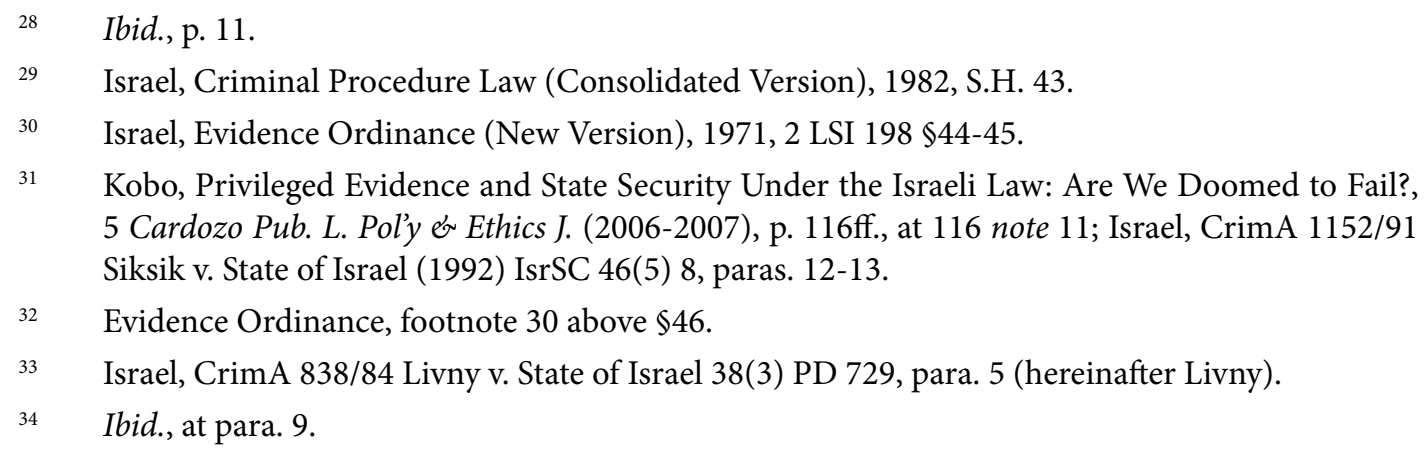


Finally, the court itself must check to see if the privilege is warranted, and whether is it essential to the defense's case. All three must employ a balancing test - they must balance the rights of the defendant against the rights of other individuals in society or those of the state, whom they are trying to protect. The difficulty that holds true for all three procedural steps is that neither the accused nor their counsel are aware of the content of the privileged evidence, so they cannot bring to light other facts that could lead the authorities to a different decision.

\subsubsection{Terrorist detention and due process}

The procedure outlined above deals with the right of access to privileged evidence after a charge has been filed against a terror suspect. In administrative detention hearings a person is arrested without being charged. Here too, classified information is shielded from the suspect, diverging from regular adversarial practice and denying certain rights under due process. The legal sources that regulate this procedure may be found in the Emergency Powers (Detention) Act of $1979^{35}$ for Israelis and the Incarceration of Unlawful Combatants Act of $2002^{36}$ for the detention of foreigners suspected of terrorist activities. Palestinians from the West Bank may also be detained under Administrative Detentions Order No. $1591 .{ }^{37}$ In all three instances, the detainee may file an appeal with the Israeli Supreme Court. The presiding judge, both in the initial proceedings and during the appeal, may withhold evidence from the detainee and their lawyer if they believe that disclosure may "impair state security or public security." 38 This means that secret evidence may be used much more extensively in the case of administrative detentions than in a regular criminal prosecution.

However, the judicial management model that the Israeli criminal system has incorporated seeks to remedy these absences by prescribing full disclosure to the judge on the case, allowing for the values of fairness and accuracy that due process espouses. This judicial practice, initiated by the Israeli Supreme Court, allows the confidential evidence to be presented to the judge on the case in the absence of the suspect themselves. After the prosecutor has presented the secret evidence, the judge may order an investigation of the

35 Israel, Emergency Powers (Detention) Act, 1979, 33 LSI 89. Under this law the detainee has the right to have their detention reviewed within 48 hours and after that every 3 months.

36 Israel, Incarceration of Unlawful Combatants Act, 2002. Under this law the detainee has the right to have their detention reviewed within 14 days and after that every 6 months. State authorities may detain unlawful combatants, or persons who have taken part in hostilities against Israel.

37 Israel, Military Order Regarding Administrative Detention (Judea and Samaria) (No. 1591,) 2007. Under this order, a person must be brought before a military judge within 8 days of their arrest to determine if their detention is justified. They may then be detained for a period of 6 months based on 'public security' concerns, which may then be extended 6 months at a time.

38 Emergency Powers (Detention) Act, §6. 
agents of the Israeli Security Agency who collected it. The judge then makes a decision about whether or not to extend the administrative detention. ${ }^{39}$

It is apparent that both in routine criminal trials and with administrative detentions, the Israeli judge plays a central role. This method was instituted as a compromise between considerations of due process and crime control. The judicial management model also employs an inquisitorial approach in what is otherwise an adversarial justice system. Recalling our discussion about the type of truth a criminal justice system seeks, it is easier now to argue the merits and pitfalls of this policy. The active judge in the inquisitorial tradition has been found to naturally develop a bias when they are pre-exposed to the background of the case before they ask questions to witnesses. ${ }^{40}$ On the other hand, the adversarial system also has shortcomings, as not all evidence comes to light, but rather only the evidence supportive of either the prosecutions or the defense's case. ${ }^{41}$ Which "truth" is pursued is unclear: while factual truth would mean ascertaining a full factual accounting of the events in question, legal truth is the determination of whether or not it is possible to find someone guilty of a certain crime. ${ }^{42}$ Consequently it would be erroneous to declare one method more effective than the other.

Under the crime control model, there is an assumption that security services and prosecutors may be trusted to sift through the information and cases before them and only pursue those who are clearly guilty, even if this assessment is based on secret evidence. Current estimates are that about 10,000 people are being held in Israeli prisons after undergoing criminal trials on various counts, as compared to about 170 being held in administrative detention based on secret evidence. ${ }^{43}$ Perhaps the system has successfully kept itself in check, and secret evidence is only used in administrative detentions where absolutely necessary, when criminal prosecution becomes impossible.

Appeals serve a similar purpose. In administrative detention hearings, in order to help balance the suspect's lack of access to the evidence, there are three instances, or three separate judgments with three separate judges, who may review the secret evidence and decide whether detention is still the necessary conclusion. Likewise, under the regular criminal process there are various stages before a case goes to trial - the opening of the investigation, the decision to prosecute, possible plea bargains. From those cases that do go to trial, most end in convictions. This may indicate that the "sifting process" in the

$39 \quad$ Krebs 2012, p. 667.

40 Damaska, Presentation of Evidence and Factfinding Precision, 123 U. Pa. L. Rev. (1974-1975), p. 1083ff., at 1092 .

$41 \quad$ Damaska 1974-1975, p. 1093.

$42 \quad$ Ibid., p. 1086.

43 As quoted during the Israel Democracy Institute, International Conference on the Use of Secret Evidence in Judicial Proceedings: Democratic Principles and Practical Experiences (December 1617 2012) 
initial stages of criminal procedure is sufficient. Alternatively, as has been underlined by an overwhelming majority of literature to date, that without seeing the evidence, the security forces cannot be trusted. "Respect but suspect" is a recurring motto. ${ }^{44}$ A study of rhetoric in jurisdprudence may help us determine which direction Israeli judges are tending towards.

\subsubsection{Legal precedents - in theory}

It is important to survey the rhetoric of cases dealing with secret evidence in order to get an "inside" look into the thoughts of decision-makers. If the due process model takes precedence when it comes to secret evidence, additional caution has to be applied to ensure that the innocent will not be wrongly convicted, even at the price of letting the guilty go free. ${ }^{45}$ The Israeli judiciary in particular has been lauded for restraining excessive executive power in times of national security crises. ${ }^{46}$ Former President of the Israeli Supreme Court Aharon Barak noted that "Democracy ensures us, as judges, independence. The real test of this independence comes in situations of war and terrorism...Precisely in these times of war and terrorism, we must embrace our supreme responsibility to protect democracy and the constitution." ${ }^{47}$ On the most basic level, the court has released detainees based on substantial ${ }^{48}$ and procedural ${ }^{49}$ flaws. Such technical review upholds the traditional due process model. Nonetheless, assuming that national security concerns demand the nondisclosure of evidence, the difficulty still remains whether or not this type of judicial review sufficiently preserves the essentials of due process.

$44 \quad$ Just a few examples are: Krebs 2012; Kobo 2006-2007; Dratel, Ethical Issues in Defending a Terrorism Case: How Secrecy and Security Impair the Defense of a Terrorism Case, 2 Cardozo Pub. L. Pol'y \& Ethics J. (2003-2004), p. 81ff.; Awan, The Erosion of Civil Liberties: Pre-Charge Detention and Counter-Terror Laws, 84 Police J. (2011), p. 272ff.; Helms, Procedural Democracy and the Terrorist Threat, 4 Police Stud Int'l Rev. Police Dev. (1981-1982), p. 23ff.; Fichera, Compromising Liberty for National Security: The Need to Rein in the Executive's Use of the State-Secrets Privilege in post-September 11 Litigation, 62 U. Miami L. Rev. (2007-2008), p. $625 \mathrm{ff}$.

$45 \quad$ Packer 1968.

46 Blum 2008, p. 13.

47 Barak, Human Rights in Times of Terror - A Judicial Point of View, 28 Legal Stud. (2008), p. 493ff, at 494 .

48 Israel, HCJ 907/90 Zayad v. Military Commander in the W. Bank (unpublished decision) (1990).

49 Israel, HCJ 7/48 Al-Karbuteli v. Minister of Def. 2(1) PD 5 (1950); Israel, HCJ 95/49 Al-Khouri v. Chief of Staff 4(1) PD 34, 41, 48 (1949); Israel ADA 7/88 A. v. Minister of Def. 42(3) PD 133 (1988); Israel, ADA 1/82 Kawasma v. Minister of Def. 36(1) PD 666 (1982). 
To help alleviate this difficulty, Israeli Supreme Court judges have taken an especially activist approach when reviewing classified evidence. ${ }^{50}$ The presiding judge has an all-encompassing role in the proceedings - they are charged with evaluating the validity and credibility of the evidence, which they then must weigh against other considerations of due process in the case. This is exemplified in the case Barham v Justice Colonel Shefi, where Justice Or stated "the fact that certain 'material' constitutes valid administrative evidence, does not exempt the judge from examining its degree of credibility against the background of the other pieces of evidence, and the entirety of the case's circumstances." ${ }^{51}$

Another, more recent, case further emphasises the importance of the judge's role in probing privileged evidence. In $A v$. State of Israel, the appellant argued against the constitutionality of section 5(e) of the Unlawful Combatants Act, which allowed divergence from the normal laws of evidence ${ }^{52}$ and, according to the appellant, infringed on their right to personal liberty. In writing her decision then President Beinisch considered the legality of examining privileged evidence ex parte and Israel's unique and persistent security situation. ${ }^{53}$ She found that an acceptable balance was struck, based on a judge's obligation to question the quality and quantity of each piece of privileged evidence, coupled with their careful consideration of the implications of suppressing certain aspects of due process. ${ }^{54}$

In addition to this heightened scrutiny of secret evidence, a judge is also charged with working for the defence, insofar as they are expected to review and question the evidence from their viewpoint. The verdict Livni exemplifies this approach with its stringent balancing test and strict requirement that information be divulged when it is essential to the defence of a suspect in a criminal trial. ${ }^{55}$ This was repeated in other verdicts such as Greenberg $v$ State of Israel. ${ }^{56}$ In administrative detention cases dealing with secret evidence, this position was expressed by the Supreme Court time and again in verdicts such as Khadri v IDF Commander in Judea and Samaria (2004), ${ }^{57}$ Federman v. Commander

50 Goldstein, The Protection of Human Rights by Judges: The Israeli Experience, in Judicial Protection of Human Rights: Myth or Reality?, eds. Gibney Frankowski (Praegner Publishers 1999), p. 55ff.

51 Israel, HCJ 4400/98 Barham v. Justice Colonel Shefi 52(2) PD 337, 346 (1998).

$52 \$ 5(e)$ of the Unlawful Combatants Act.

53 See Israel, CrimA 6659/06 A v. State of Israel 62(4) PD 329 para 43 of President D. Beinisch (2008).

$54 \quad$ Ibid.

$55 \quad$ Livny supra note 33, para. 5.

56 Israel, CrimA 1924/93 Greenberg v. The State of Israel, (1993) IsrSC 47(4) 766, 771.

57 HCJ 11006/04 Kadri v. I.D.F Commander in Judea and Samaria (unpublished decision para 6 (2004). 
of the Central Command (2005), ${ }^{58}$ and Agbar v. I.D.F. Commander in Judea and Samaria (2007). ${ }^{59}$ The Supreme Court expects judges to speak on behalf of the detainee, since they cannot defend themselves against evidence they cannot see. This much more activist role is not characteristic to the traditional role of a judge in an adversarial system, ${ }^{60}$ and again the Israel system seems to combine inquisitorial with adversarial practices, or crime control concerns with due process rights.

This has different implications with respect to due process. A recent article focused on three specific values of due process - participation, accuracy, and regulation of state powers - and evaluated how the judicial management model fulfilled each one. ${ }^{61}$ The first function of due process was the opportunity for the accused to participate in the legal process and defend themselves. In this regard, the Israeli judicial model is lacking. Though the judge on the case is meant to participate on behalf of the defendant, this does not replace the personal knowledge the defendant may have that could effectively contradict the secret evidence. Even an alternative special advocate model, which will be addressed further in this article, was not deemed to be completely efficient. This is because while the special advocate is fully exposed to the confidential evidence and is meant to step into the shoes of the accused and participate on their behalf, they are never allowed to share the contents of the secret evidence with them. ${ }^{62}$

The second function of due process was defined as accuracy, requiring criminal procedure to check facts and prevent error. In this case, the Israeli judge is considered a successful protector of due process concerns. Specifically, the inquisitorial role they take on requires that they recreate the story being presented to them as precisely as possible. ${ }^{63}$ Of course, if this story turns out to implicate rather than exonerate the accused, this function of due process is nonetheless fulfilled. This may be an easier role to accomplish in systems used to the inquisitorial tradition than those where the judges do not usually take on this level of involvement.

The third function of due process is to systematically regulate state powers. ${ }^{64}$ Based on their repeated involvement in cases that include secret evidence, judges gain the nec-

58 Israel, HCJ 5555/05 Federman v. Commander of the Central Command 59(2) PD 865, 869 (2005).

59 Israel, HCJ 9441/07 Agbar v. I.D.F Commander in Judea and Samaria(unpublished decision) para 8 (2007).

60 Israel, Administrative Detention App. 6183/06 Gruner v. Minister of Defense (unpublished decision) (2006), Justice Cheshin.

61 Barak-Erez and Waxman 2009.

62 Ibid., pp. 37-39.

63 Ibid., pp. 40-41.

64 Ibid., at note 137; Lord Woolf et al., De Smith's Judicial Review, $6^{\text {th }}$ ed (Sweet \& Maxwell 2007) pp. 318-319. 
essary experience to allow them to review the system as a whole. In this way they can review the practice of security services objectively, decide if and where they are lacking, and use their apolitical agenda to improve the system. This is especially true in Israel, where cases that involve secret evidence such as detention cases go to a limited group of judges (presidents of district courts and justices of the Israeli Supreme Court in cases of appeal). The regulation of state powers can do much to alleviate the fear that courts automatically concede their judicial review to executive power in times of national emergency. Israel, in particular, may benefit from the enforcement of this aspect of due process since it has declared itself to be a in a state of emergency from the time of its foundation.

\subsection{4. (Detention) Legal Precedents - in practice}

Notwithstanding that this approach strives to fill in the gaps of secret evidence procedure, in practice not all aspects of due process are necessarily safeguarded. In a study of 322 Israeli administrative detention cases from 2000-2010 where secret evidence and $e x$ parte proceedings were regularly used, there were no rejections of secret evidence and no release orders issued in even a single case ${ }^{65}$ Such findings reveal a difference between the rhetoric of the cases quoted above, and the actions of the judges in practice. While the judges interviewed in this study were aware of the precedents guiding them when it came to scrutinising secret evidence, they expressed apprehension at challenging prosecutors and investigators, with whom they had developed trusting professional relationships. ${ }^{66}$ This entailed marginal involvement when it came to testing the secret evidence. Instead, judges center their arguments around the law guiding them, by interpreting legal limits on the uses of secret evidence, and not by actually challenging the evidence at hand. This is one way in which due process was affected. Another is that the detainee and their lawyer were never given the opportunity to challenge the secret evidence that was relied upon by the judges. ${ }^{67}$ In this way, the practice resembles a crime control model, insofar as judges efficiently pass the secret evidence through and allow the detention of suspected terrorists, but there is a significant absence when it comes to testing the reliability of the evidence.

On the other hand, the same study done of these 322 cases also focused on the mediation efforts that go on "in the shadow" of the court, behind the scenes. The author takes a negative approach to these non-court proceedings and indicates that the settlements reached are in all likelihood not to the advantage of the detainees, even though many are released as a consequence of these settlements, since they are still blind to the evidence against them. It may be possible to argue just the opposite - that due to the pressure of the

\footnotetext{
$65 \quad$ Krebs 2012, p. 687.

$66 \quad$ Ibid., pp. 683-687.

67 Ibid.
} 
court, many are freed despite the secret evidence, or even because of it. Since the judges are uncomfortable with the secret evidence process, they prefer that the two sides come to an agreement outside of court, which may work to the detainee's advantage. Even the author agrees that "the Court has chosen these alternative means of communicating its scepticism about weak cases." ${ }^{\prime 8}$ This would indicate that due process rights are being afforded to the detainees, albeit outside of court.

Practically speaking, the results of the 10-year case study are discouraging. There is a widespread use of secret evidence and no detainees are released via judicial proceedings. While the judge is meant to play an active role in examining secret evidence, they mostly rely on the Israeli Security Agency (ISA) and are reticent to challenge them during the in camera ex parte hearings. Despite these misgivings some still maintain that judges are crucial in checking executive authority in times of national security crises, and are the best suited to provide legitimate decisions based on their repeated experience and political non-affiliation. ${ }^{69}$ The judges' awareness of their fragile position must also influence their decisions. Thus, in practice, the Israeli judicial management model does not necessarily dictate that terrorist defendants should be treated like regular criminal defendants, but that they should be held to a different standard altogether.

\section{Comparative Law - Counter-Terrorism, Secret Evidence and Criminal Procedure. Efforts to Advocate Due Process.}

To determine if Israeli standards are up to par when it comes to due process it is possible to compare Israeli criminal procedure with that of other states. International law struck an interesting balance between due process and crime control, and different states have applied various measures in order to comply with human rights standards. When applying international legal standards to Israeli criminal procedure, Justice E.E. Levy found that:

It is in the nature of things that differences may arise between the rules of international humanitarian law - especially written rules - and the language of Israeli security legislation, if only because those conventions that regulate the conduct of players on the international stage were formulated in a very different reality, and their drafters did not know of entities such as the Hezbollah organisation and the like.

Therefore, insofar as it is possible to do so by means of legal interpretation, the court will try to narrow these differences in a way that realises both the principles of international law and the purpose of internal legislation. ${ }^{70}$

$68 \quad$ Krebs 2012, p. 681.

69 Waxman, Can Courts be 'Trusted' in National Security Crises?, 1 Found for Law, Justice and Soc'y (2009)

70 A v. State of Israel, footnote 53 above, Justice E.E. Levy 
The common factor to all states when it comes to criminally prosecuting terrorist crimes under international legal standards is a concern about human rights. ${ }^{71}$ This concern often arises when secret intelligence is used in criminal investigations and prosecutions of terror suspects since this information is inadmissible in many states. The right to a fair trial as enshrined in international human rights conventions is then put at risk. Still, states attempt to ensure that criminal investigations and pre-trial detentions live up to international human rights standards. It is interesting to establish whether these foreign states tend toward the crime control model or the due process model, in establishing a base standard for when secret evidence may be used against terrorist suspects.

\subsection{International legal standards}

The international legal context that guides the use of intelligence information may be found in such conventions as the European Convention on Human Rights (ECHR) ${ }^{72}$ and the International Covenant on Civil and Political Rights (ICCPR). ${ }^{73}$ These international instruments comprise the right to a fair trial, which includes the right of an individual to know the case against them, and the right to a fair and public hearing. While certain human rights may be somewhat restricted for the sake of national security, ${ }^{74}$ even an emergency situation does not allow the derogation from the right to a fair trial. ${ }^{75}$ In a report on terrorism and human rights, the Eminent Jurists Panel reaffirmed this when they found that the use of intelligence as secret evidence challenges the principles of a fair trial. ${ }^{76}$

Case law has reflected this finding. As early as 1996 the European Court of Human Rights (ECtHR) dealt with an immigration detention in Chahal v. United Kingdom and found that UK had violated Article 13 of the ECHR and did not afford Chahal sufficient protections because the materials used against him in his immigration hearing were kept secret from him and the court. ${ }^{77}$ In the well-known case of A. v. United Kingdom, the ECtHR allowed for some evidence to remain closed, but not when the final decision about the detention of a terrorist suspect was based solely on closed materials. ${ }^{78}$ It

71 Eijkman and van Ginkel, Compatible or incompatible? Intelligence and Human Rights in Terrorist Trials, 3(4) Amsterdam Law Forum (2011), pp. 3-16.

72 Article 8 ECHR.

73 Article 14 ICCPR; see also article 10 of the Universal Declaration of Human Rights (UDHR).

74 Article 6 ECHR, article 14 ICCPR.

75 UN Human Rights Committee, General Comment 29, States of Emergency (article 4), U.N. Doc. CCPR/C/21/Rev.1/Add.11 (2001): Emergency situations do not justify divergence from fair trial.

76 The Eminent Jurists Panel on Terrorism, Counter-terrorism and Human Rights, Assessing Damage, Urging Action, International Commission of Jurists 2009.

77 Chahal v. United Kingdom, 1996-V ECtHR 1844-46.

78 A. v. United Kingdom, Appl. No. 3455/05, ECtHR 2009. 
pointed out in its decision that each case must be reviewed in order to determine what standard of disclosure is necessary. ${ }^{79}$ Thereafter, the British House of Lords found in a decision about secret evidence that a terrorist suspect must be made known about the core, or "essence" of the case against them. ${ }^{80}$ What exactly defined this "essence" was not specified, but there was an insistence on finding a balance between security and ensuring suspects a fair trial. Likewise, in Wassink $v$. the Netherlands the ECtHR concluded that to balance the principles of security and fair trial, information may be withheld under certain circumstances, but not all information. ${ }^{81}$

To implement this balance, a number of countries have instituted special procedures for using secret evidence or intelligence in criminal prosecutions of terrorists. For example, in the Netherlands, the Witness Identity Protection Act ${ }^{82}$ passed in 2006 allows for intelligence to be used in criminal court cases via submission in an official report, and for the hearing of shielded witnesses to be heard in ex parte and in camera by a special examining magistrate. This Act is complicated by the fact that it is difficult for the trial judge to evaluate the reliability of the official reports submitted in writing and that the defence is unaware of the origins of the evidence submitted and cannot cross-examine the witnesses.

In France, the relevant procedure is established by the Law on the Fight Against Terrorism and on Various Dispositions Concerning Security and Border Control. ${ }^{83}$ Under this legislation, an investigating judge controls the pre-trial criminal investigation into a terror suspect, and once criminal proceedings have begun, the defendant has complete access to the case file and the evidence included therein. The investigating judges on terror cases have regularly used intelligence during the investigative stage, and the judges work closely with intelligence services. During the pre-trial period, the investigating judge must request declassification of secret documents if they are considered to be relevant to the case, and if the judge is granted access the evidence is added to the case file and all parties may view it. However, while the defendant and their counsel do have complete access to all information included in the case file, they are unable to determine which techniques are used in deciding which information to add in the first place. ${ }^{84}$ Furthermore, the close working relationship between the investigative judge and intelligence

\footnotetext{
$79 \quad$ Ibid., para. 203.

80 Sec'y of State for the Home Dept. v. AF (2009) UKHL 28, para 65 (Lord Phillips).

81 Wassink v. Netherlands, Appl. No 12353/86, A-185A, ECtHR 1990. As cited by Eijkman and van Ginkel 2011.

82 Act of 28 September 2006 (Stb. 2006, 460).

83 'Law on the Fights Against Terrorism and on Various Dispositions Concerning Security and Border Control' (Loi 2006-64).

84 Eijkman and van Ginkel 2011.
} 
services may compromise the impartiality of the decisions made about which evidence to pursue.

Accordingly, different countries have taken distinctive measures in trying to maintain human rights while ensuring national security, with varying degrees of success. A closer look at the UK, Canada, and the US will be taken in the next section, in order to present a comparative analysis to Israel's system. These countries have chosen to implement different methods in dealing with secret evidence. The use of special advocates in the UK and Canada may be compared and contrasted with the Israeli judicial management model, to see if implementation of these special attorneys might help alleviate some of the challenges in the Israeli system. In the US, the combination of the special advocate and judicial management model serves as an interesting comparison to the current Israeli method.

\subsection{UK, Canada - Special Advocates}

The ECtHR case law that criticized the broad use of secret evidence ${ }^{85}$ served as an impetus for both Canada and the UK to implement a special advocate system. ${ }^{86}$ Under this system a special attorney may gain access to secret evidence that is not disclosed to the suspect or to their other legal representatives. The special advocate is charged with representing the interests of the terror suspect, but they are unable to reveal the secret information to the suspect nor meet with them after seeing the closed materials without court permission. This means that when they appear in a closed adversarial hearing they have a few goals in mind. First, they are charged with trying to contest the state's arguments based on the secret evidence that only they have been exposed to. They will also argue for further disclosure of the evidence to the suspect themselves, so that they might lend to their defense. ${ }^{87}$

In Canada, non-disclosure of secret evidence is regulated by the Canadian Evidence $\mathrm{Act}^{88}$ which determines pre-trial, trial and appellate procedure when dealing with sensitive information. The Canadian Immigration Act also dictates procedure when it comes to secret evidence. ${ }^{89}$ Canadian citizens suspected of terrorist acts will see the evidence against them in court, but non-citizens may be subject to a removal request where a security certificate is issued and then the suspect will only receive a summary of the secret information being held by the government. A special advocate system was implemented

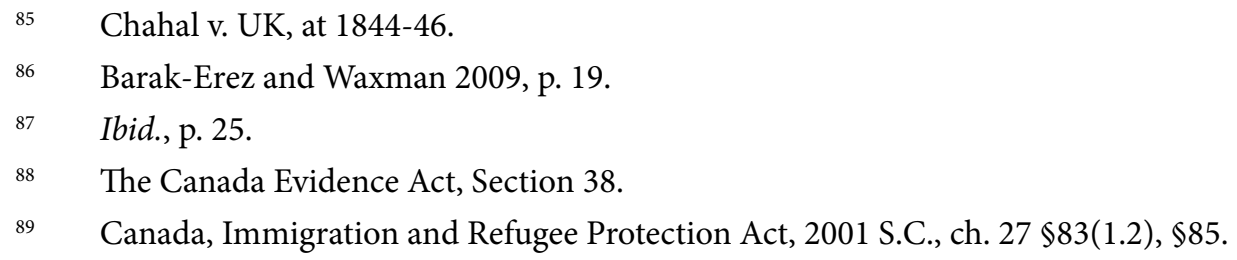


after the Canadian Supreme court determined that this summary does not guarantee the right to a fair trial. ${ }^{90}$

Canadian special advocates are lawyers appointed by the court. They function independently from the government and have security clearance to access secret information. They are charged with protecting the interests of the defendant while keeping the information that may harm national security confidential. A special advocate may communicate with the defendant before they see the confidential evidence protected by the security certificate, but communication after special proceedings are subject to judiciary approval. Thus, the defendants themselves never have access to the secret evidence and is not aware of the sources of said evidence.

Similar to the Canadian system, the UK also employs special advocates when using intelligence information in criminal proceedings where there are national security concerns. ${ }^{91}$ The use of special advocates was originally introduced in immigration proceedings, and then integrated into terrorist hearings through the Prevention of Terrorism Act of $2005 .{ }^{92}$ The implementation of this system initially satisfied human rights concerns about the use of secret evidence that arose in the ECtHR case of Chahal $v . U K,{ }^{93}$ where it was argued that the former UK system was in violation of the ECHR since the accused and their lawyer had no opportunity to challenge secret evidence serving as the basis for judicial decisions. However, since then the use of secret evidence has increased and become commonplace in terrorism related trials, and human rights concerns have been revived. ${ }^{94}$ In 2010, the UK Joint Committee on Human Rights found that the use of special advocates is contrary to Common Law and Article 6 of the ECHR, ${ }^{95}$ as certain evidence is never disclosed to the defendant, directly or indirectly.

When assessing the special advocate system in a comprehensive manner, it is immediately apparent that it holds certain advantages over the Israeli system, and entails certain drawbacks that the Israeli courts manage to avoid. On the one hand, special advocates ensure a procedural check on governmental powers in cases drawing on secret evidence. The special advocate approach upholds the adversarial tradition, maximising the "participation" of the accused by having an attorney arguing on their behalf, cross-examining witnesses, and challenging the evidence to the best of their legal ability. This attorney is solely concerned with defending the interests of the accused. In this way the adversarial

90 Supreme Court of Canada, Charkaoui v. Canada, 2007 SCC 9, 1 S.C.R. 350.

91 As per the Terrorism Act 2000 and Anti-terrorism, Crime and Security Act 2001.

92 United Kingdom, Prevention of Terrorism Act, 2005, c. 2, \$1.

93 European Court of Human Rights, Chahal v. The United Kingdom, 70/1995; 22414/93; (1996) 23

EHRR 413; [1996] ECHR 54. Chahal footnote 78 above at 1844-46.

$94 \quad$ Eijkman \& van Ginkel 2011 pp. 3-16.

95 Joint Committee on Human Rights. Counter-Terrorism Policy and Human Rights (Seventeenth Report): Bringing Human Rights Back In. Sixteenth Report of Session 2009-10, p. 23. 
system is sustained and aligned with due process concerns. This comes in contrast to the Israeli judicial management model, where the judge is expected to represent both the accused and the government, notwithstanding their competing interests.

On the other hand, the role the special advocate must play is complicated by an unclear definition of their responsibility towards the defendant in Canadian and UK legislation. ${ }^{96}$ Moreover, their inability to discuss the evidence with the suspect after seeing the confidential information will make it difficult to successfully argue for greater disclosure. This is compounded by the fact that they are also prevented from seeing earlier closed decisions dealing with secret evidence in a system that heavily relies on precedent. The presence of a special advocate risks having the opposite effect of the one intended. That is, the government may choose to reveal even less evidence to the terror suspect directly, on the basis that the special advocate will have the opportunity to scrutinise this evidence instead. ${ }^{97}$ This is true for the Israeli system as well, with the judge able to see the evidence.

\subsection{US - Judicial Management and Special Advocates}

In the United States, secret evidence is used against terror suspects in criminal prosecutions, military court-martials and in immigration proceedings. This section will focus on the initial stages of American criminal procedure, such as the discovery stage of evidence in criminal prosecutions. Due process rights afforded to a suspect are both constitutional and based on legal precedent. Most importantly, the US Fifth and Sixth Amendments guarantee a suspect due process, including inter alia the rights to contribute to their defence, to a public trial, to be informed of the nature of the case against them, and to be confronted with the witnesses against them.

When it comes to federal criminal prosecutions, two major statutes prevent these rights from being fulfilled - the Foreign Intelligence Surveillance Act (FISA), ${ }^{98}$ and the Classified Information Procedures Act (CIPA) ${ }^{99}{ }^{100}$. The former allows covert surveillance and gathering of foreign intelligence against a suspect, and the latter regulates, inter alia, access to classified information and the use or admission of such secret evidence into criminal proceedings. ${ }^{101}$ In court martial proceedings, Military Rule of Evidence 505 similarly limits the use of secret evidence, and allows the government to submit a sum-

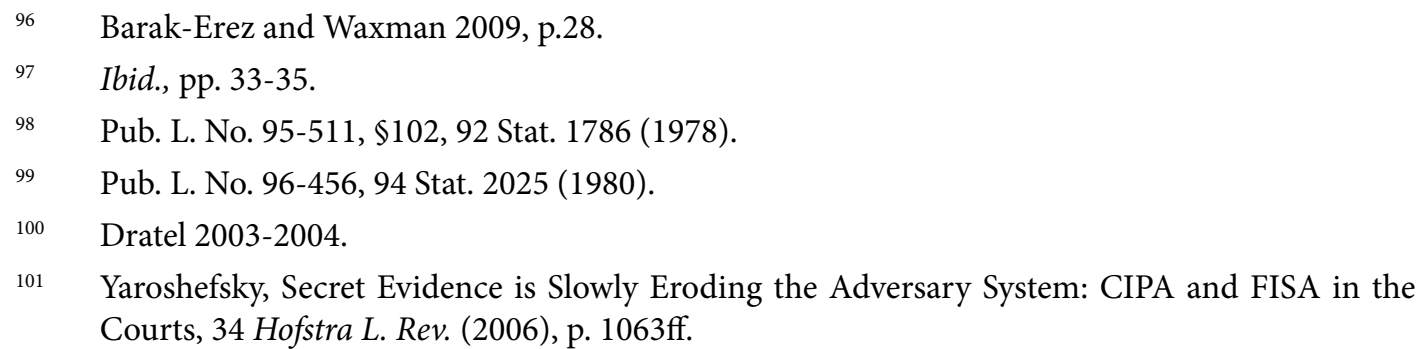


mary of classified documents in lieu of the evidence. ${ }^{102}$ In the immigration milieu, sometimes there is no need to hold a hearing, let alone introduce the secret evidence against a person suspected of terrorism. ${ }^{103}$

Under FISA the government must seek a warrant from a specially designated FISA court by demonstrating that its purpose is to gather foreign intelligence and not to pursue criminal prosecution. However, many times the person under surveillance is prosecuted and the evidence obtained is then subject to discovery. When this happens the defendant may not see the original FISA warrant and is prevented from gaining access to all of the FISA wiretaps of their conversations. Furthermore, judicial review is limited insofar as the court cannot analyse whether the original warrant was justified. This means that the defendant's right under the Fourth Amendment to only being searched based on "probable cause" is complicated. Once the case goes to prosecution, the government may selectively declassify certain communications and not others. FISA becomes even more complicated when coupled with CIPA and exacerbated by the 2001 Patriot Act. ${ }^{104}$

CIPA outlines a comprehensive procedure for handling classified information, which addresses both discovery and its admissibility during a trial. If the government has classified information that may be relevant to the case, CIPA section 4 dictates that it present this information ex parte and in camera to the trial court to decide if this information is discoverable, without input from the defence counsel. If the court determines that this information is indeed relevant and helpful to the defence's case, it must apply a balancing test that weighs a standard of relevance against government privilege. Should the information be considered discoverable, the government may be ordered to disclose the classified information, or to submit a summary of the information to the defence. If the government refuses to disclose the evidence, the court may dismiss the the claim altogether. $^{105}$

In a military court martial trial of a non-US citizen suspected of terrorism, ${ }^{106}$ the accused and their civilian lawyer may be refused access to secret evidence based on the Military Rule of Evidence 505. The accused's military lawyer, who must be appointed for their defence, is allowed access to this information, but may not disclose it to the accused or their civilian counsel. ${ }^{107}$ This prevents the accused from contributing to defense. This is

\footnotetext{
102 Mil. R. Evid. 505(g)(2).

103 Immigration and Nationality Act $\$ 235(\mathrm{c})$ (I) (2000).

104 Patriot Act, 50 U.S.C. $\$ 1801-11$ (2001). FISA powers were amended by the PATRIOT Act .

105 Act of Oct. 15, 1980, Pub. L. No. 96-456, 94 Stat. 2025 (codified as amended at 18 U.S.C. appx. $\$ 1-16(2003))$

106 Military Order of November 13, 2001: Detention, Treatment and Trial of Certain Non-Citizens in the War Against Terrorism, 3 C.F.R. 918, 918 (2002)

107 US Dep't of Defense, Military Commission Order No. I, Procedures Against Terrorism (Mar. 21, 2002), 32 C.F.R. $\$ 9.1-9.12(2004)$
} 
in contrast to two major precedents that, when taken together, indicate non-citizen suspects should be granted constitutional protection. Hamdi v. Rumsfeld ${ }^{108}$ established that citizens must have a real opportunity to defend themselves, and Rasul v. Bush ${ }^{109}$ extended such due process rights to non-citizens as well, albeit on a minimal level. ${ }^{110}$

In the immigration context, expedited removal proceedings, detention of an alien pending resolution of their immigration proceedings, and removal proceedings before the Alien Terrorist Removal Courts all involve the use of secret evidence. ${ }^{111}$ Under expedited removal proceedings and Alien Terrorist Removal Courts secret evidence may be used against an arriving alien suspected of terrorist involvement, and they may not be permitted to access any of that information. ${ }^{12}$ Similarly, it has been established that if an alien is detained based on national security considerations, undisclosed classified information may be used if they appeal for a redetermination of their custody status. ${ }^{113}$ Therefore, aliens suspected of terrorist involvement have practically no procedural protection, and may be denied admission into the country based purely on confidential information.

The challenges these different procedures pose are numerous. The court during the ex parte hearing may not be in position to decide whether certain material is essential to the case of the defense. When CIPA or other measures are activated in terrorism cases a heightened standard of relevance is applied when balancing due process against national security, which results in the defendant rarely gaining access to secret materials. ${ }^{114}$ Should information be deemed discoverable, only a lawyer with security clearance or a military appointed counsel may examine the classified materials. Furthermore, even if they do see the evidence, counsel may not reveal information from the classified material to the defendants themselves. If evidence is given in summary form, defense lawyers find it difficult to uncover exculpatory details. ${ }^{115}$ In immigration cases many times none of the evidence is disclosed at all.

In summary, the decision to suppress evidence in the initial stages of American criminal procedure may be compared to Israeli criminal procedure and detention proceedings. Not only does the American procedure dealing with secret evidence largely resemble Israeli procedure, both have also been subject to similar criticism. The trend in the US is to make the use of secret evidence entirely commonplace. This along with the fact that American judges tend to defer to the executive branch in times of national security,

124 S. Ct. (2004), p. $2633 \mathrm{ff}$. 124 S. Ct. (2004), p. 2686ff.

Note, Secret Evidence in the War on Terror, op.cit. at note 1. Ibid. 8 U.S.C.A $\$ 1101-1537$ (2000 \& Supp. 2004)

Note, Secret Evidence in the War on Terror, op.cit. at note 1.

Yaroshefsky 2006, pp. 1067-1068.

Dratel 2003-2004. 
means that the judiciary alone cannot be relied upon to ensure a defendant's rights when it comes to due process. ${ }^{116}$ This is especially true when it comes to the Fourth, Fifth and Sixth Amendments rights. However, the introduction of a cleared counsel that is allowed access to intelligence information is an interesting attempt to blend the judicial management and special advocate models. Perhaps this type of clever combination could be used in Israeli criminal procedure as well.

\section{Israel's Counter-Terrorism Memorandum Bill - A New Model Of Evidential Procedure, Or More Of The Same?}

A new piece of legislation is under consideration that addresses evidential procedure of terrorist suspects. On July 27, 2011 the Israeli Counter Terrorism Memorandum Bill, 5771-2011 was published, and is currently undergoing ammendments in the Israeli Knesset. The bill's explanatory note begins by introducing the bill and explaining its goals, which include providing Israeli authorities with the necessary tools under criminal and public law to counter threats of terrorism, and to address terrorist activity not covered by previous laws such as unconventional terrorism and the use of chemical or biological weapons. ${ }^{117}$ The bill purports to do so by synchronising and unifying existing anti-terrorist rules into one comprehensive piece of legislation. The bill's authors recognise the difficulty to grant wide enough legal tools to effectively counter the severe threats to national security while still protecting democratic values and human rights.

There are two main pieces of existing legislation that the proposed bill seeks to replace and modify: the Prevention of Terrorism Ordinance 5708-1948 and the Prohibition of Terrorism Financing Act 5765-2004. The memorandum does not revoke counter-terrorism provisions of the Defence (Emergency Regulations) Act of 1945. While the attempt to unify counter-terrorism legislation has been lauded, certain aspects of the bill have been criticised, such as the broad definitions of terms associated with terrorism which have major implications for how the rest of the bill is applied. ${ }^{118}$ Aside from these new extended definitions, the proposed law also sometimes alters previous legal procedure.

One example is the administrative detention of terror suspects. Under the new law, suspects may be held up to 96 hours before being brought before a judge, and may be detained without charge for up to 30 days. ${ }^{119}$ When court hearings take place, secret ev-

116 Yaroshefsky 2006.

117 Israel, Counter Terrorism Memorandum Bill, 5771-2011, Explanatory note to $\S 1$.

118 See Israel Democracy Institute's review of the Counter Terrorism Memorandum Bill, http:// www.idi.org.il/sites/english/ResearchAndPrograms/NationalSecurityandDemocracy/ Terrorism_and_Democracy/Newsletters/Pages/17th\%20newsletter/1/1.aspx, published on April 21, 2010 (last accessed on December 19, 2014).

119 Counter Terrorism Memorandum Bill, note 177 above, $§ 50-57$. 
idence is ever-present. Hearings may be held without the suspect present, and the right to legal counsel may also be withheld. Statements by witnesses who are not present are admissible. These procedures laid out in the bill are based on Section 5 of the Defense (Emergency Regulations) Act of 1945. However, international precedents cited in this article do seem to indicate that this falls short of Israel's international legal obligations and that the use of secret evidence should be minimised. This is based on the ECtHR judgement $A$. And Others $v$. the $U K$, under which even during a state of emergency which allows for derogation from certain ECHR rights (or the equivalent ICCPR), a person must still be given a fair chance to defend themselves in court. ${ }^{120}$

Another change may be found in the bill's conditions for forfeiture of property and freezing of assets of suspected individuals or organisations. ${ }^{121}$ The bill addresses three major kinds of confiscation - the first regarding criminal procedure, the second civil procedure (which together make up chapter 6), and the last administrative procedure (chapter 7). The provisions found in chapters 6 and 7 are mostly based on the Prohibition of Terrorism Financing Act 5765-2004. However, this law did not allow for the use secret evidence in civil proceedings on forfeiture of property, whereas the proposed bill does. ${ }^{122}$ This also means that a terror suspects may be prosecuted in criminal proceedings and simultaneously have their property seized through the use of secret evidence under a civil procedure. This amounts in other words to a double use of secret evidence.

The use of secret evidence extends further : whereas the Prohibition of Terrorism Financing Act foresees the forfeiture of property after a conviction in criminal proceedings for two specific crimes (transactions with terrorist property or transactions with property for the purposes of terrorism) $)^{123}$ it also allows the judge a discretionary power to quash the forfeiture. On the other hand, the proposed bill unconditionally requires confiscation after a conviction. ${ }^{124}$ Forfeiture of property in a civil proceeding under the previous law was only allowed after an act of terrorism that took place outside of Israel, and did not allow for forfeiture of property unconnected to the crime. ${ }^{125}$ This is in contrast to the current bill. ${ }^{126}$ For all of these reasons, the bill has been the object of criticism that claims it does not proportionately protect the human rights of the victims of forfeiture who are third parties and only indirectly connected with the acts of terrorism. of Human Rights, 19 February 2009.

121 Counter Terrorism Memorandum Bill, note 117 above, chapters 6-7.

$122 \quad$ Ibid., $\$ 56-59$.

123 Israel, Prohibition on Terrorist Financing Law, 2004, §8, §9, §12.

124 Counter Terrorism Memorandum Bill, note 117 above, $\$ 58$.

125 Prohibition on Terrorist Financing Law, note 123 above, $\$ 22-24$.

126 Counter Terrorism Memorandum Bill, note 117 above, \$64-68 .
} 
While prior laws had different procedures with regard to submitting confidential evidence in civil hearings, the proposed bill offers an explanation for the changes. The extensive use of confidential evidence is justified by the unique needs of the fight against terrorism, the importance of blocking terrorist financing which enables terrorist activity, and the nature of the evidence that usually relates to such financial activity. ${ }^{127}$ The bill also claims to take a comparative approach and incorporate other nations' practice. However, responses have been varied internationally, and as we have seen many countries found different ways of balancing human rights concerns and preventive terrorist legislation. Therefore, while the Israeli bill purports to protect human rights as much as possible, the changes in legal procedure broadening the use secret evidence may infringe on suspects rights to due process under international standards. ${ }^{128}$ In addition, the perpetuation of the use of secret evidence in proceedings against terror suspects only complicates the difficulties presented by existing legislation and procedure. It seems that the equilibrium between crime control and due process has been altered.

\section{Conclusion: Does The Threat Of Terrorism Justify The Use Of Secret Evidence?}

Much of Israeli criminal procedure that deals with secret evidence affords wide discretion to human judgment; the investigative authorities collecting the evidence testifying at in camera hearings, the prosecutor making a judgment call about whether to privilege certain information, the Minister signing a 'certificate of opinion'. And, of course, the judge who has all of this information before them and must perform a balancing act when deciding whether privileged evidence should remain so, or whether the detention of a suspect based on secret evidence is justified. All of these actors are pieces of a puzzle, trying to adhere to the law guiding their decisions. If the challenges posed by the use of secret evidence are related to the officials functioning under procedural law, then the solution must be tailored to these officials. Likewise, if the procedure itself is flawed, perhaps that should be the focus of improvement.

Whichever of these aspects is to be emphasised, the theoretical basis of the system is paramount. The crime control and due process models insert a system of checks and balances at very different stages of the process. Concerns such as efficiency, equality, reliability, factual guilt versus legal guilt - all play different roles depending on which model

127 Counter Terrorism Memorandum Bill, note 117 above, $\$ 68$ in the explanatory note.

128 For example, Article 13-14 of the Convention Against Terrorist Bombings and Article 17 of the Convention Against the Financing of Terrorism, as cited in O' Donnel, International Treaties Against Terrorism During Armed Conflict and by Armed Forces, 88 International Review of the Red Cross (2006), p.853ff. 
is chosen, and affect different phases of procedure. So too an inquisitorial or adversarial tradition will influence how procedure and procedural reform are employed.

Israeli legal procedural currently allows secret evidence in the initial stages of criminal procedure in two main instances. The first is during standard criminal prosecution when the state chooses to privilege certain evidence and shield its transfer to the defence. The second is during administrative detention hearings. In both cases the Israeli judge is afforded the widest discretion in making decisions about the secret evidence. They may determine whether to lift the privilege and to have the evidence be exposed for use during a criminal trial. They contemplate the evidence when making decisions about whether to extend the duration of a detention, knowing that the suspect themselves has no knowledge of its contents.

The language used by this central player, the judge, about the use of secret evidence, shows great deference toward both crime control and due process values. The judge tries to make factual determinations about the suspect, while at the same time considering whether or not legal guilt may be verified. At the same time, the tenuous security situation that Israel finds itself in is never neglected. The balance sought between the two, however, may not materialise on a practical level, given that most decisions based on secret evidence are in favour of the state.

If Israel is operating under a crime control model, and its security and investigative personnel are reliable, even more deference may be given to investigative officials. In contrast, if Israel is basing its system on due process, the most accurate way of predicting legal guilt is by exposing the suspect to all the evidence against them. Current procedure may reflect an attempt to reach a compromise between the two, albeit not a perfect one. Moving forward, other countries may provide good examples of how to improve this balance. This will be especially true should Israel's preference be tipped in favour of one of the models over the other, as reflected in the Counter-Terror Memorandum Bill. It must not be forgotten that there is an inherent risk when modifying existing standards, as the lifting of restrictions on secret evidence may actually encourage the legislator to institute greater checks in the system and impose stricter procedures as means of balance.

The majority of literature on secret evidence has addressed how holding certain information confidential from a suspect affects their civil liberties and human rights. It has also considered the necessity of secrecy given the threat of terrorism. This article has argued that it is arduous to criticise or reflect on current procedures concerning terror suspects and secret evidence, without first considering the theoretical substructure of criminal procedure. In the case of Israel, security and due process have simultaneously been emphasised by the criminal system since its establishment. The success or failure of the judicial management model can only be determined when weighed on the scale of the state's commitment to crime control or due process. 